\title{
Emil Novak (1884-1957) and the Novak curette
}

\author{
M. Thierry
}

(C) Springer-Verlag 2010

The name of this American gynecologist-pathologistanatomist remains eponymously linked to the suction curette that he described in 1935 for collecting (without the use of anesthetics) a substantial amount of endometrial tissue for microscopic examination.

Emil Novak was born on 8 March 1884 in Baltimore, Maryland, USA, in the city that following the founding of the Johns Hopkins Hospital in 1889 and the Johns Hopkins School of Medicine in 1893 became in America the epicentre of modern medical studies [1-4] (Fig. 1). He was the firstborn of 12 children. His parents were immigrants from Bohemia (the Austrian-Hungarian Empire). His father made his living as a tailor and had to work hard to provide his large family with the absolute essential needs. He sent Emil to free city schools. When he reached his 18th birthday, his father decided he had picked up enough of an education and was ready to become a tailor. But the school principal, supported by the family doctor, disagreed and managed to get the boy to finish his secondary schooling and, subsequently, and on condition that he would secure the needed funds, to attend courses at the "Baltimore Medical College". In 1904, Emil Novak obtained his MD diploma magna cum laude.

Dr. Novak established himself as a general practitioner and specialized in gynecology and surgery at the city hospital (the "Maryland Medical Hospital"). Within 1 year of his promotion, his Alma Mater appointed him "Associate

Novak also wrote "Memoir of Dr. Meyer" as an introduction to the “Autobiography of Dr. Robert Meyer. New York: Henry Schuman, s.d.

M. Thierry

Foundation Jan Palfyn and the Museum of Medical History,

Ghent, Belgium

M. Thierry $(\square)$

Aan de Bocht 6,

9000 Ghent, Belgium
Professor of Gynecology", a position he retained until 1915. The year 1915 was a turning point for his career. Sought out by the famed Hopkins "Department of Gynecology," Dr. Novak became there the assistant (instructor) to Thomas Cullen (1868-1953), Chief of the Department of Gynecologic Pathology" [1]. Cullens' own collection of microscopic preparations turned into a goldmine for the assistant to collect materials for his initial publications. Until the end of his life, Novak will remain associated with the "Hopkins Medical School." It was there that he was awarded the title of "Associate Professor of Gynecology" and where he succeeded Cullen as Chief of the "Pathology Lab." Professor Novak died on 3 February 1957 in Baltimore from cardiac complications.

Dr. Novak led a hectic life. As the nation's prominent pathologist in gynecology-obstetrics, he acquired great international renown. Nevertheless, he never secluded himself within the confines of the laboratory ivory tower. He told one of his biographers just 1 year prior to his passing away: "Pathology is just a hobby for me. All my life, my routine has been operating in the morning, seeing patients in the afternoon, burning midnight oil, and pathology at odd times" [2]. He wrote during the evenings, often well into the night, publishing some 160 articles, primarily on pathological anatomy, and two classical textbooks: "Gynecological and Obstetrical Pathology" in 1940, and "Textbook of Gynecology" in 1941 [3, 4].

With Nicholson J Eastman (1895-1973), the Hopkins professor of obstetrics, Novak was in 1946 the driving force in the publication of the journal "Obstetrical and Gynecologic Survey," wherein he summarized important international publications and offered his comments on their content and merits. These comments were scientific-literary pearls, thoughtful, spirited, and spiced with sometimes rather risqué observations that not always pleased his serious-minded co-editor. 


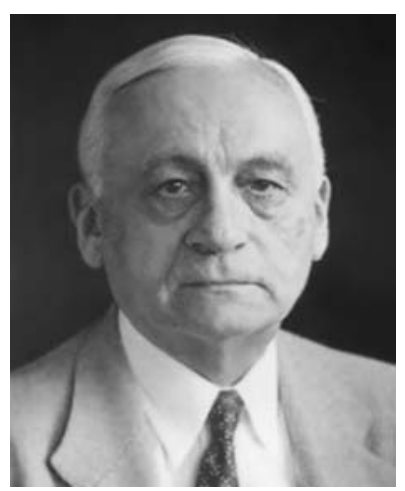

Fig. 1 Emil Novak

Novak became co-founder (1929) and twice chairman of the "Baltimore Obstetrical and Gynecological Society". In 1947, he was chairman of the "American Gynecological Society". He was awarded with the distinction of Doctor Honoris Cause by several national and international universities and made an "Honorary Fellow" of the "Royal College of Obstetricians and Gynaecologists" of England.

Novak has made a large number of contributions to gynecological and obstetrical pathology. He started on his detective trail in the twenties with the study of the histology of the endometrial cycle. This led him to the study of the earliest stages of cervical neoplasm (carcinoma in situ) and of uterine carcinoma (adenocarcinoma corporis uteri) and to paying special attention to the possible relationship between endometrial hyperplasia and cancer. He studied endometriosis and chorionic carcinoma, and, in 1947, founded the "Chorionepithelioma Registry".

After Robert Meyer, his idol, presented a lecture in 1939 to the "American Gynecological Society" about hormoneproducing ovarian tumors, Novak in turn decided to study these mysterious tumors of which the "Path Lab" possessed many samples. Three years later, he was approached by the "American Gynecological Society" to start a register of rare cases of ovarian tumors. Novak involved his mentor Meyer

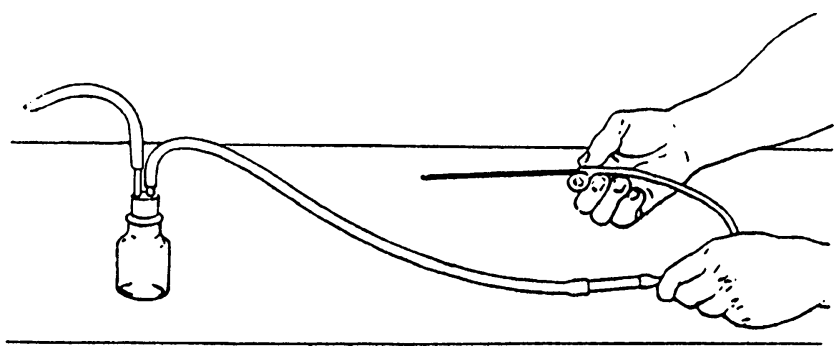

Fig. 2 The Novak suction curette [6] in this initiative. Meyer was a Jew who in 1939 had been expelled from his laboratory at the Berlin "Charité" and had found a new home country in the USA. Novak welcomed his spiritual father with great affection. We are indebted to Novak's articulate pen for the touching biography of Robert Meyer, the father of gynecological pathology [5].

The current generation of gynecologists associates the name Novak only with the endometrial curette that he introduced in a brief article entitled "Suction-curet apparatus for endometrial biopsy," published in 1935 in the JAMA. A thin metal pipette, either straight or bent, the rounded-off end ending on a serrated eye. Novak connected the curette to a rubber catheter and a flask to collect the shaved off tissues [6] (Fig. 2) He found this little device handy, no more than that. He made "no claim as to the originality of the principle of the apparatus, for the suction idea has long been employed by many gynecologists". New were the "serrated fenestrum" of the curette and the electrical motor used to achieve the relative vacuum. The Novak curette is still being used today, albeit without the vacuum motor. The principle of continuous aspiration remains applicable in $\mathrm{D}+\mathrm{C}$, especially in cases where a malignancy is suspected [7].

\section{References}

1. Robinson J (1949) Tom Cullen of Baltimore. Oxford University Press, London

2. Berkow SG (1956) A visit with Dr Emil Novak. Obstet Gynecol 7:107-113

3. Novak E (1940) Gynecological and obstetrical pathology. Saunders, Philadelphia

4. Novak E (1941) Textbook of gynecology. Williams \& Wilkins, Baltimore

5. Novak E (1947) Life and works of Robert Meyer. Amer J Obstet Gynecol 53:50-64

6. Novak EA (1935) A suction-curet apparatus for endometrial biopsy. JAMA 104:1497-1498

7. Hurtig A (1961) Continuous suction during dilatation and curettage. Wissenschaftliche Ausstellung 3. Weltkongress der Internationalen Federation für Gynäkologie und Geburtshilfe. Kongresskomitee und Sandoz AG, Basel

\section{Further Readings}

8. Gill RS (1954) About Emil Novak. Obstet Gynecol Surv 9:1-13

9. Martzloff KH (1957) In memoriam Dr Emil Novak. West J Surg Obstet Gynecol 65:107-110

10. Peel J. The Lives of the Fellows of the Royal College of Obstetricians and Gynaecologists 1929-69: W. Heineman, 1970 